\title{
3.Г. Сактаганова
}

\author{
Центр этнокультурных и историко-антропологических исследований, \\ Карагандинский государственный университет им. Е.А. Букетова, Казахстан \\ (E-mail: zauresh63@mail.ru)
}

\section{Женская повседневность на фронтах Великой Отечественной войны (на основе материалов Комиссии по истории Великой Отечественной войны)}

\begin{abstract}
Статья посвящена исследованию повседневной жизни казахстанских женщин на фронтах Великой Отечественной войны. Цель данного исследования - актуализация внимания на проблемных моментах женской фронтовой повседневности (трудности, быт, мужской шовинизм, насилие). Автором на материалах интервью, собранных Комиссией по истории Великой Отечественной войны (Научный архив ИРИ РАН, ф. 2), повествуется об истории повседневной жизни женщин Казахстана на фронтах Великой Отечественной войны. Отслежены некоторые сюжеты судеб и истории участия казахстанских девушек в войне; приведены фрагменты стенограмм бесед с ними в период Великой Отечественной войны.
\end{abstract}

Ключевые слова: Великая Отечественная война, история Казахстана, Комиссия Минца, советские женщины, женщины на фронте, женская повседневность.

\section{Введение}

Осенью 1941 г., в первые месяцы Великой Отечественной войны, возник вопрос о необходимости накопления и сохранения материалов по истории Великой Отечественной войны. В сентябре 1941 г. на расширенном заседании Президиума Академии наук СССР была поставлена одна из главных задач перед Институтом истории АН СССР - составление летописи войны. Из записей дневников И.И. Минца сохранилась об этом запись: «25 ноября 1941 г. в Москве т. Александров Г.Ф. ... сообщил, что создана Комиссия по собиранию материала и подготовке «Летописи Отечественной войны». Начать надо с «обороны Москвы» и постепенно расширять работу. Мне поручено связаться с остальными научными учреждениями, привлечь людей...» [1].

Уже в январе 1942 г. при Академии наук СССР была создана Комиссия по истории Великой Отечественной войны (чаще упоминаемая как комиссия Минца). Во главе данной Комиссии были назначены начальник Управления агитации и пропаганды ЦК ВКП(б) Г.Ф. Александров и член-корреспондент Академии наук СССР И.И. Минц (профессор, доктор исторических наук, специалист по истории российских революций и гражданской войны); о последнем позже писали, что он «один из официальных и наиболее почитаемых лидеров советской исторической науки» [2; 157]. Комиссия по истории Великой Отечественной войны начала свою деятельность как Комиссия по истории обороны Москвы (декабрь 1941 г.), в январе следующего года, как отмечалось выше, она была преобразована в более широкую структуру по своим задачам и охвату проблемы. Деятельность этой Комиссии, как отмечают исследователи, по «масштабам развернутой работы, широте тематики, уровню ее научной организации и методического обеспечения в военные годы была наиболее плодотворной» [1]; в ней «наиболее полно и квалифицированно были реализованы в годы войны усилия научной общественности страны по сохранению личностных документов о Великой Отечественной» [3; 17]. Комиссия выполняла роль Всесоюзного археографического центра по истории войны, координировала и направляла работу местных комиссий, в том числе национальных республик (в 1943 г. Комиссия по сбору материалов по истории войны была создана и в Казахстане).

Сбор материалов осуществлялся по нескольким аспектам: история воинских частей, партизанское движение, оборона городов, материалы о Героях Советского Союза, военная экономика, национальные республики в годы войны, культура, быт и т.д. (эти темы впоследствии были отражены в названии и содержании разделов). Однако после 1953 г. материалы Комиссии Минца были проверены и «пересистематизированы»: часть документов передана в другие учреждения, архивы, спецхран., часть - уничтожена [4; 129-130].

Оставшиеся материалы Комиссии хранятся в Научном архиве Института российской истории Российской академии наук (НА ИРИ РАН). Они составляют два фонда: небольшой комплекс 
организационно-распорядительных документов и значительный по объему массив документов, в том числе личного происхождения, собранных Комиссией. В архиве собрано более 16000 дел, из которых около 4000 - стенограммы и записи бесед с участниками войны. Основным методом сбора материалов было интервьюирование очевидцев событий, участников военных сражений, героев войны; осуществлялись стенографирование или запись бесед и воспоминаний интервьюируемых. Ценность и значение именно этих материалов подчеркивал руководитель Комиссии И.И. Минц: «Мы документы не собираем... Мы записываем живых людей» [5].

Документы Комиссии представлены в 14 разделах (общая характеристика этих разделов, их описи представлены на сайте НА ИРИ РАН [1]). Несмотря на интереснейшие собранные материалы, источники из фонда Комиссии Минца в казахстанской исторической науке использованы крайне ограниченно. И значительный пласт материалов по Казахстану до сих пор не введен в научный оборот.

\section{Методы и материаль исследования}

При написании статьи были использованы различные общенаучные методы: общелогические методы исследования - анализа и синтеза, аналогии, обобщение, системного подхода, методы эмпирического исследования - сравнения, описания, методы теоретического познания — формализация, абстрагирование и др. Использовались и специальные исторические методы: сравнительно-исторический метод при изучении и анализе бесед и воспоминаний женщин-фронтовиков, микроисторический подход, позволяющий проследить влияние макрособытий на тактику выживания, мышление, оценку, поведенческие стереотипы женщин в военные годы и др.

Материалы о казахстанцах и Казахской ССР в годы войны в большей степени представлены в нескольких разделах. В I разделе «История воинских частей и подразделений» (всего 124 дела), например, в Ф. 2, Оп. 28, Д. 1-37, представлены стенограммы бесед с военнослужащими 8-й стрелковой дивизии им. Панфилова, воспоминания бойцов и командиров, списки демобилизованных. Раздел IV включает «Материалы о Героях Советского Союза»; из 11657 Героев Советского Союза, получивших Звезду в годы войны, были сохранены стенограммы бесед с 7240 Героями (в их числе есть и казахстанцы). Раздел V «Тыл, военная экономика» - небольшой по объему, состоит из 678 дел. Незначительное количество материалов в нем посвящено работе колхозов Алма-Атинской области. Раздел VII «Национальные республики в годы Великой Отечественной войны» состоит всего из 49 дел. В числе других республик представлен и Казахстан. В описи по нашей республике имеется 13 дел, из которых Дело 1 - с материалами делегации трудящихся Казахстана на Брянский фронт; Дело 3 - с материалами об участии казахстанцев в защите Москвы; Дело 4 - писатели и артисты Казахстана в дни Отечественной войны; Дело 5- о передовых женщинах Казахской ССР; Дела 6 и 7 - письма с фронта; Дела 8 и 13 - с материалами о деятельности колхозов КССР; Дело 12 - стенограмма беседы с К.А. Сатпаевым и т.д. В разделе X «Отдельные документы, не вошедшие в другие разделы» имеется опись 7, представленная 79 делами о женщинах в Великой Отечественной войне, среди которых есть и уроженки Казахской ССР.

В данной статье скомпонованы стенограммы бесед из НА ИРИ РАН (материалы Комиссии по истории Великой Отечественной войны из Фонда 2) с девушками-фронтовиками. Это документы, касающиеся участия казахстанских женщин в военных сражениях, из раздела I «История воинских частей и подразделений» и раздела $\mathrm{X}$ «Отдельные документы, не вошедшие в другие разделы».

\section{Результаты и их обсуждение}

Несмотря на уникальность материалов, собранных Комиссией И.И. Минца, исследований, основанных на этих документах, не так много. В годы войны эти документы оставались долгое время невостребованными. Первый документальный монографический труд в российской историографии об истории создания, основных направлениях деятельности и результатах, вкладе ученых-историков, работавших в Комиссии по истории Великой Отечественной войны для сохранения исторической памяти о войне в военные годы, был опубликован лишь в 2015 г. коллективом ученых Института российской истории РАН [5]. До этого времени материалы Комиссии использовались в публикациях нечасто, ряд статей вышли в советское время $[6,7]$. Некоторый всплеск обращения и изучения источников из Фонда 2 Комиссии Минца российскими исследователями наблюдался в последнее десятилетие [8-10]. Опубликованы совместные работы российских и зарубежных историков с привлечением материалов Научного архива ИРИ РАН [11-13]. 
В казахстанской историографии публикаций, основанных на материалах Комиссии по истории Великой Отечественной войны из НА ИРИ РАН, немного. В рамках реализации проекта по истории Великой Отечественной войны нам удалось поработать в данном архиве с материалами Комиссии об участии казахстанцев в войне, в частности, со стенограммами бесед с девушками: летчицей Доспановой Хиуаз (в стенограмме она записана как Екатерина), снайперами Скрипочкиной Александрой и Лобковской Ниной.

Приведем краткую характеристику девушкам-фронтовикам из материалов Комиссии.

1. Доспанова Екатерина [Хиуаз], летчик-бомбардировщик, гвардии лейтенант, после ранения назначена начальником связи 46-го гвардейского авиационного бомбардировочного, ночного, ордена Красного знамени, ордена Суворова Таманского полка, 325-й авиационной дивизии 4-й воздушной армии. Служила на 2-м Белорусском фронте. 1922 г. рождения, казашка. Член ВКП(б) с 1943 г. Награды: орден Отечественной войны II степени; орден Красной звезды; медаль «За оборону Кавказа». Беседа состоялась в апреле 1945 г. [14; 1].

2. Скрипочкина Александра Сергеевна, гвардии сержант, снайпер, член партии с 1942 г. Родилась в 1918 г. в г. Алма-Ате; родители - служащие. Награждена медалью «За боевые заслуги»; орденом Отечественной войны II степени. Беседа проведена в январе 1944 г. [15; 3].

3. Лобковская Нина Алексеевна, гвардии ефрейтор, снайпер ... ударной армии Прибалтийского фронта, командир армейской роты снайперов-девушек, русская, родилась в 1924 г. в селе Федоровка Карагандинской области в семье служащих. Награды: орден Красного знамени; медаль «За отвагу». Стенограммы трех бесед были записаны 15 марта 1944 г. и 4, 5 октября 1945 г. [16; 1]

Приведенные фрагменты в формате «живого общения» с героинями беседы позволяют прочувствовать эпоху времени. Причем эти беседы не были строго ограничены рамками анкеты, поэтому девушки могли высказать свою точку зрения по каким-то вопросам, сказать или же вскользь упомянуть те или иные аспекты повседневности (достаточно щекотливые с точки зрения господствующей идеологии или табуирования данных тем для молодой советской девушки-коммуниста), с которыми им пришлось столкнуться и которые не могли быть обозначены в советское время в открытой печати.

Детальное чтение и анализ этих текстов позволяет выявить некоторые из проблемных моментов в военной женской повседневности. В целом, для содержания всех стенограмм бесед с девушками характерен высочайший патриотический подъем, идеологически выверенная идейная направленность и целеустремленность, типичная для советского человека оценка непростой ситуации в эти военные годы, жертвенность и готовность к преодолению трудностей, подвигу во имя страны, Сталина, вера в победу, отсутствие пессимистических или негативных настроений. Но отслеживаются порой в них и нетипичное для советского времени озвучивание проблем, трудностей, фактов проявления мужского шовинизма и насилия над девушками и др. (главное и, пожалуй, удивительное - это фиксация и сохранение данных моментов в стенограмме). Публикация такого рода материалов в советских исследованиях была невозможной, поэтому сохранение этих стенограмм «без купюр», без цензуры - очень важный момент сбережения цельности исторической памяти, военной действительности.

\section{Партиотизм, жертвенность, ежедневный подвиг на фронте}

Х. Доспанова: «Враг подходил к Москве. В ЦК комсомола узнали, что проводят набор девушек в армию. Я и еще несколько девушек едем в ЦК, а там девушек видимо-невидимо. Все такие восторженные, воинственные. Я твердо ответила, что решила идти на фронт. Куда, кем на фронт ничего не знала, знала лишь, что Раскова формирует. Мы думали, что нас оставят охранять аэродромы. Разбили всех на три группы: летная, штурманская, вооруженная.

В штурманской группе были одни студентки, занимались прекрасно. Штурманскую группу называли «профессорами», «аристократией». Было обидно и лестно. Летчики, механики были на аэродроме, а мы занимались теорией. Нам устроили подъем в 6 часов утра, мы попросили, чтобы в 5.30, чтобы 30 минут позаниматься азбукой Морзе - морзянкой. В то время в голове была одна лишь учеба и одно желание - скорей бы на фронт. Училась я в штурманской группе, летала с летчиком Белкиной на тренировочных полетах и была бесконечно счастлива. Учили мы все прилежно, хорошо. Раскова не раз подчеркивала, что мы несем честь советской женщины. Она говорила: «Девушки войны, ваша честь - честь советской женщины, вы понесете ее в Европу, не оскандальтесь». Мы все время вспоминали ее слова.

В мае 1942 г. я первый раз пошла на боевое задание. Казалось, что непременно погибну. Обстреляли нас, но были бесконечно рады: получили боевое крещение. А потом пошло все нормально. На 45 
вылете с нашим самолетом произошла авария - при взлете самолет врезался в столб. У меня был перелом голеностопного сустава. 5 месяцев пролежала в госпитале, а потом стала летать с летчиком Юлией Пашковой. Чудная девушка, с огоньком.

Когда я почти совсем поправилась, Галя Докутович рассказала мне о гибели девушек. После поправки я настояла пойти опять в полк и летать. Должна отомстить за погибших девушек, чувство долга перед погибшими девушками заставляло меня летать. Из кабины я не вылазила, сделаешь 5-6 вылетов, не выходя из самолета, потому что было больно ногам, в кабину подсаживали. После катастрофы я сделала еще 100 вылетов. В полетах после катастрофы я совершенно не обращала внимания на зенитный огонь, а обращала лишь внимание на самолеты в воздухе, поэтому со мной было трудно летать. Да и мне самой было очень трудно, болели ноги. Меня назначили начальником связи полка. Здесь я стала уделять много внимания партийно-комсомольской работе.

Девушки очень дорожат честью полка, ради полка готовы на любые жертвы. У нас всегда чисто. Не делаем различия дома ли, на фронте ли. Мы любим музыку, книги, труд, любим жизнь, за свое счастливое будущее и своих детей летали без устали на боевые дела, хоронили друзей и вновь бомбили, пока не разбомбили вконец» [14; $1-3]$.

А. Скрипочкина: «В начале войны я подавала заявление в армию, но меня не взяли. Зимой 1942 г. вызвали в военкомат и направили в Москву в школу снайперов. Сначала здесь были 4-месячные курсы, потом прибавили еще 2 месяца, и образовалась школа.

... Чтобы дать возможность нам получить боевой практический опыт, было приказано на время прикрепить нас к снайперам-мужчинам. Старые снайпера помогали нам в открытии счета. Они болели за нашу работу, им хотелось, чтобы каждый прикрепленный к ним снайпер открыл счет. Они показывали те участки, где больше всего появляется немцев, где расположены их огневые точки. Снайпер говорит: «Стреляй». А я не могу. Даже дрожь в ногах появилась. Все же выстрелила и, видимо, попала. Немец выпрямился, затем упал на бок. Его было хорошо видно. Мы наблюдали около часа, немец лежал без движения. Никто к нему не подходил. Таким образом, я первая из 40 девушек открыла счет».

Вопрос: «Как действовали девушки на фронте?»

«Мы старались вплоть до того, что всех немцев уничтожали. Зачем ему жить, раз можно его убить. Но там, где мы были, немцев почти не было, а были власовцы. Они дерутся до последнего. Немцы сдаются в плен, а они нет. Потери были большие, но среди девушек не было. Нам приходилось перевязывать, вытаскивать раненых с поля боя.

Орден я получила за следующую операцию. 7, 8 и 9 ноября мы заняли несколько деревень. Подошли к деревне Пугачиха. Я была в 7-й строевой роте, когда наше подразделение пошло на деревню, помощник командира по политчасти сказал нам, чтобы не ходили. Затем, видя, что он отвернулся, мы побежали за бойцами. Противник открыл пулеметный огонь. Половину деревни заняли наши, а в другой половине были немцы. На одной окраине деревни наши стреляют, на другой - немцы. Я залегла около копны сена и начала вести огонь. Я подавила пулеметный расчет противника, но у меня вышли патроны, а бойцы не подают. Я пошла собирать патроны. Ко мне подошла моя снайперская пара и говорит, что раненых много, а перевязывать некому. ... Сама она не может. В доме был большой ящик, оставленный немцами. Я полезла в ящик, и там оказались медикаменты, перевязочные материалы, немецкие бинты, вата. Мы начали перевязывать.

В роте я осталась одна. Уничтожила 16 фрицев. Под утро командир роты мне говорит: «Пойдите, часок-два отдохните, день предстоит тяжелый. Придется работать, может быть, одной». Я доползла до ячейки, но винтовку оставила в общей траншее. Оттуда кричу командиру роты, что нужны винтовка и плащ-палатка. Связной принес плащ-палатку, а винтовку не принес. Хорошо, что кто-то оставил ППШ. Связной едва успел мне передать плащ-платку, как был ранен и умер.

Я взяла его ППШ. После артналета приполз связной и притащил мою винтовку. Смотрю, к немцам с тыла подошла автомашина с винтовкой. Один из немцев командует около автомашины. Я убила офицера, остальные спрятались за автомашину. Но себя я выдала, и автоматическая пушка открыла огонь по моей точке. Они столько били, что весь бугорок сравняло. Было очень страшно, так как я была одна. Так пролежала целый день. За это наступление и я получила орден Отечественной войны II степени».

Вопрос: «Какую характеристику можно дать девушкам?»

Общая характеристика хорошая. Девушки комсорги работают замечательно. Занимались изучением приказа товарища Сталина, изучением работы парторга на фронте, проводят учебу с бойцами, чтобы они знали оружие, доводят до каждого бойца приказы» [15; 3-7]. 
Н. Лобковская: «Мы были на Птахинской высоте, где были сильные бои, и где противник сделал 35 контратак, только тяжелых снарядов оставил больше 350 и больше 400 трупов. Противник уже стих к нашему приезду на сопках напротив. Мы даже видели траншеи его в зигзагах. На следующий день, когда один фриц пробегал из траншеи в траншею, я его уничтожила. Он не особенно трудно мне достался и поэтому подробностей я не запомнила. Но это был первый, уничтоженный мною фриц, записанный в моей снайперской книжке.

Дня через три эта позиция меня уже не удовлетворяла. Метров 30 от нас стоял подбитый немецкий танк, и я решила сходить за передний край к этому танку. А нам туда не разрешали ходить, так как везде были мины. Я все же пробралась к подбитому танку. Я залезла в нижний люк, там все разрушено, много пробоин. Посидела, смотрю, рядом с сиденьем пробоина и видна вся оборона, как на ладошке. Я решила, что обязательно здесь буду, ориентировочно все посмотрела, где поставлю винтовку. Пробралась опять туда с винтовкой и шинелью. А сижу я на высоте, да еще на танке, мне сверху все хорошо видно. Летом и у нас, и у немцев мало народу, движение не наблюдается, особенно днем. Я наблюдала, а потом подумала: не заброшенная ли эта траншея. Вдруг, часов через 12 появляется фриц. Я - раз! - и хлопнула его. А за мной никто не наблюдает. Поднялась, там суматоха в траншеях. А когда он нагнулся, мне уже не видно фрица. Наверное, его стащили. Через некоторое время смотрю - куст ползет. А кругом тихо, безветренно, каждый кустик заметен. И я вижу, что куст шевелится. Видимо, связист. За куст держится, тянет кабель и опять движется. Там было недалеко, метров 400. Ну, думаю, возьму-ка тебя сейчас в оптику. Он не всегда равномерно подвигал куст. Тут я увидела и контур каски. Стала караулить его. Когда он загибал в мою сторону, я увидела его лицо. Тут, как раз, у него было какое-то препятствие, он его перелезал, а я — бац! - и убила его в это время. Мы обыкновенно ведем огонь пристрелочными пулями, и в этот момент меня обнаружили. Слышу разрыв снаряда - недолет. Попал не в танк. А там каждое местечко было пристреляно и наблюдалось. Меня обнаружили и пошли садить по танку. Второй недолёт. А потом как загудел весь танк. Я напряглась, растерялась, скорей винтовку схватила и голову под сиденье. Думала, что, если голову спрячешь, так все в порядке. Пять мин он пустил в меня: одну в башню, одну в лоб и третью в гусеницы попал. Мне ничего не сделалось. А между нами было всего 15 метров. Тут я быстро вылезаю, подхватила винтовку и пробежала во весь рост по этому месту благополучно. Черных мне заверил двух фрицов, но командир роты меня ругал за то, что я вышла без разрешения и назначил мне пять суток строгого ареста. А для этого надо было самой выкопать яму в три метра глубины и три метра ширины и в ней сидеть. Ну, конечно, меня потом простили за двух фрицов.

Учеба в школе нам много дала, вполне достаточно для фронта. А фронт нам дал боевую закалку. Во-первых, мы не стали бояться снарядов... Во-вторых, мы научились распознавать тактику противника, его режим дня. И, в-третьих, научились выбирать места. Всего мной убито 52 фрица с августа 1943 г. и по январь 1944 г.

Перед нашим отъездом были сильные бои за переправу. Числа 17 декабря в районе Демешкино, Орехов ручей, Прудино и Гатчино, особенно, шли большие бои. 21 дивизия участвовала на прорывах сильной обороны. Немецкий корректировщик - «костыль» разнюхал нашу переправу, и через некоторое время началась бомбежка. Три раза в сутки бомбили. Потери мы несли там жуткие. И противник здесь как раз и прорвался. В первый день он произвел пять контратак. Мы отбили. За этот день мы еще заняли вторую линию обороны. Силы у нас были, а потом подошел еще учебный батальон. В 6 часов утра начался сильный бой. В этот день мы отбили 13 контратак силами 6 девушек и 15 бойцов. Правда артиллерия нам помогла, и был хороший подвоз боеприпасов. В боях мы работали и за медсестер, и за связистов. Там сняли корректировщика с дерева, там наблюдателя, а во время контрнаступления мы снимали их командиров. Вот за это многие из нас получили ордена и другие награды в благодарность от командующего армией» [16;1-12].

Вопрос: «Мужской шовинизм на фронте: был или нет?»

Некоторые из интервьюируемых девушек говорили о том, что на фронте первоначально они столкнулись с мужским шовинизмом по отношению к себе: девушкам пришлось доказывать свою «полноценность» на фронте. Недоверие, насмешки, иногда неприкрытое пренебрежение после первых учений или сражений сменились на признание мужчинами равенства женщин в военном деле, а иногда и предпочтение командиров из-за исполнительности и точности в выполнении приказов. Исследователь Е. Сенявская, изучая опыт всех войн в XX веке, подчеркивает, что другая сторона феномена участия женщин в войне — «неоднозначное отношение военного мужского большинства да и 
общественного мнения в целом к присутствию женщины в боевой обстановке, в армии вообще» [17; 150]. Безусловно, что с этим замечанием следует согласиться.

Х. Доспанова: «Нас повезли в Энгельс учиться. В Энгельсе жили под славой Расковой, а то мужчины заклевали бы.

Особенности нашего полка — типично женская среда, мужского духа не было в полку. Настроены мы были так, что должны выполнить большую миссию. Все бывало: и слезы, и обиды, и общая радость от успеха полка» $[14 ; 3]$.

А. Скрипочкина: «Когда приехали в 1-й батальон 153 полка, мы построились и прошли боевым шагом. Встретил комбат с большим недовольством. Лица у всех были смущенные, прибыли 50 девушек в полном снаряжении, смогут ли они работать, могут ли вообще стрелять эти девушки-снайперы? Устроили нам вроде вторых инспекторских испытаний. Стреляли на 1000, 800 и 700 метров. Стрельба, которая производилась на дистанции, на которые мы в школе не стреляли, дала хорошие результаты: 1 или 2 - посредственно, остальные - хорошо или отлично. Мнение о нас после стрельбы изменилось. Мы в школе получили хорошую подготовку: нас учили не только снайперскому делу, но мы изучали все виды оружия, так как приходится действовать не только из снайперской винтовки, но и из автомата и пулемета. После разведки командир полка нас выстроил и благодарил снайперов за хорошую поддержку.

После этого мы поехали на армейский слет. Собрались все командиры 3-й ударной армии, генералы всех дивизий. Мы - женский армейский взвод снайперов - заняли первое место. Была дуэльная стрельба, когда выходят мужчина и девушка и стреляют на 500 метров из пулемета. Девушки победили. 11-е упражнение все девушки выполнили, а мужчины не выполнили.

Затем был организован парад. Специально привезли офицерские курсы, которые прошли строевым шагом. Потом их выстроили, сказали: «Смотрите, как девушки пройдут». Мы 49 девушек прошли строевым шагом и заняли первое место» $[15 ; 3,4]$.

Н. Лобковская (15 марта 1944 года): «Высадились в Великих Луках и долго не могли найти себе пристанища, где бы отдохнуть - все здания были разрушены. В конце концов, нас привели в какойто дом, мы переночевали, и утром после завтрака за нами пришли три машины из запасного полка. Из всех землянок бегут, на нас смотрят. На пути встретили полковника Чекалькова. Он отнесся к нам скептически: «Посмотрим, как они у вас стреляют». А майор Никифорова нам говорит: «Ну, девушки, покажем класс стрельбы». На второй день пристрелка оружия. До этого мы никогда не стреляли на большие расстояния. Сначала дали нам упражнение от 300 до 600 метров. Мы выполнили. Потом контрольные стрельбы до тысячи метров. Выполнили и это хорошо. Полковник Чекальков был доволен. Были там и представители из штаба армии. Командир полка докладывал о нашей стрельбе, боевой подготовке, дисциплине и прочее. И командующий армией решил вручить нам снайперскую книжку лично» [16; 2-3].

Н. Лобковская (4 октября 1945 года): «Потом нас присоединили к мужскому эшелону, ну тут не обходилось без небольших скандалов, споров... Вдруг встречается машина, в которой сидели командир полка и начальник штаба полка. Вид у командира был далеко неприветливый и даже пренебрежительный, что нас очень огорчило. Майор Никифорова стала говорить, что вот это девушки-снайперы. Видимо, она говорила, как мы стреляем, он сказал: «Ну, мы посмотрим, мы своих снайперов готовим». Приехали в расположение 153-го полка. Встретили нас, как нам показалось, неприветливо. Когда нас выстроили, все были поражены нашей дисциплине, мы хорошо равнялись, а как песни затянули, со всего лагеря сбежались и только слышалось: «Ого, бабы приехали! Поучиться можно! Вот идут, так идут!»

На следующий день нам устроили стрельбы. Сразу хотели дать экзаменационную стрельбу, но майор Никифорова добилась, чтобы нам разрешили пристрелять оружие. И вот на следующий день пошли пристреливать винтовки. Одни были хорошие, а другие в дороге развинтились, и приходилось их долгое время приводить к нормальному бою.

На следующий день мы выполняем упражнение, не помню не то на 300, не то на 400 метров. Упражнение выполнили прекрасно. На третий или четвертый день нам дают упражнение, которое мы в школе не выполняли, стрельбу на 600-800 метров... Все напряжены, волнуемся, чем же это закончится. Мы чувствовали, с каким недоверием к нам относились и нам хотелось доказать свое могущество, оправдать себя, и мы дрались за свою правоту. Первый день все выполняем на «5» и на «4». Командование наше очень потрясено такими успехами, они никогда не получали таких высоких 
показателей от своих снайперов, и мы были в зените радости: бегали, целовали друг друга, а вечером потребовали танцы. Мы находились на довольно приличном расстоянии от фронта $[18 ; 1,2]$.

Приехали мы в гвардейскую 21-ю дивизию. Встретили нас очень тепло. Встречал начальник политотдела дивизии полковник Толстопятенко. Тут были беседы и в отношении медицины, и в отношении политики. Комсорг полка нас привез, доложил командиру полка, познакомились с ним. Встретил он нас тоже очень хорошо, такое теплое, искреннее к нам отношение проявил. Все на нас смотрели с удивлением, как на диковину, высыпали из землянок. В полку нас опять разделили на три группы. Там нас называли и «коробочками», и «танкетками», как только не называли.

Когда у нас был армейский слет 24 августа 1943 года, мы были в 21-й дивизии на стажировке. Собрали лучших снайперов всей армии, и нас попросили туда. Приехали мы. Были представители из армии от всех дивизий. Стреляли мы замечательно. Я помню, стреляла с одним из лучших снайперов 357-й дивизии. Выстроили его и меня. Мы должны были охотиться друг за другом. Генералов было непочатый край. Мы привыкли к этому и не терялись при них. Нам объяснили задачу, выбрали место, и кто быстрее поразит противника. Я выбрала место. Вдруг появляется мишень. Я с первой пули его поразила, а он меня - со второй и третьей. А он имел 250 уничтоженных фрицев, а я в то время только 10 или 11. Генерал-майор Карапатьян из 357-й дивизии говорит: «Не может этого быть. Перестрелять!»

Нас опять на рубежи и все снова. Я прихожу, занимаю опять место, и начинается стрельба. Только появилась мишень, я снимаю опять. Нас берут с рубежей. Подходит генерал-майор ко мне: «Ну, курноска, обстреляла моего лучшего снайпера». Я покраснела. А тут народу! Все хлопают. Так торжественно: музыка, фотографируют нас всех. Потом, когда пришлось быть в 357-й дивизии, мы пришли туда всем взводом, генерал-майор спрашивает: «А кто у вас обстрелял моего снайпера?». Я поднимаю руку, и он меня представляет всему штабу дивизии: «Вот эта курноска, маленькая такая, с винтовкой за плечом, обстреляла моего лучшего снайпера». Все смеялись» $[16 ; 6]$.

И другие девушки имели хорошие результаты, и, когда подвели итог, девушки-снайперы заняли первое место. Саша Шляхова, помню, выступала. Нас поздравляли с хорошими результатами. У командования после этого появилось особенное уважение, они увидели, что люди подготовлены. После этого ни одна наша просьба не оставалась неудовлетворенной [17; 4].

Одна наша девушка Галя Кочеткова тоже проявила геройство и подняла в контратаку. В эту же ночь она погибла от прямого попадания в землянку. Вообще все наши девушки проявили большую стойкость, а бойцам было стыдно, что девушки остаются в траншеях и ведут огонь, а они бегут.

В больших походах бывает тяжело, но девушки у нас гордые и от мужчин не отстают. Даже, если заболеют, не просят их подвезти. Бывает, что и ногу раздерешь, и промочишь ноги, и на сырой земле лежишь - и все ничего» [16; 5-6].

Проблемы и проявления слабости, злости, ненависти

В стенограммах бесед иногда нарушены стереотипы поведения и оценок: девушки говорят о своих проблемах, о страхах, отклоняются от заведомо «правильных» оценок, идейной направленности, советских идеологических штампов о героизме. Именно тогда становится понятно, что они - люди, и они тоже теряют веру, надежду, сталкиваются с негативными проявлениями и реагируют на них не всегда так, как принято, когда они ведут себя не так, как положено, а как получается по ситуации. Они рассказывают о событиях, где проявляли слабость, злость, ненависть.

Х. Доспанова: «Стояли мы в Краснодаре, работали на ст. Крымская. Погода была жуткая. Немцы свирепствовали. Пошли на цель, отбомбились, идем обратно, своего аэродрома не видно. Я говорю Юле: «Мигни огнями». Только мигнула, за нами истребитель противника. Преследовал до самого аэродрома. Мы быстрее на посадку и тут опять катастрофа - столкнулись два самолета. Помню треск, шум, попыталась вылезти из самолета и упала без сознания. Оказывается, у меня было 6 переломов в ногах. Долго была без памяти, кричала Юлю. Пролежала 6 месяцев на спине, глаз тоже не видел. Свет не мил. К самолету питала отвращение. Меня хотели перевезти из одного госпиталя в другой на самолете. Я в слезы, не хочу на самолете. Все люди были не милы, жизнь перестала интересовать, стала особенно много курить. Смерть Юли Пашковой, а также Дуси Носаль от меня скрывали. Врачи уговаривали, что поправлюсь, отдохну и буду заканчивать институт. О том, чтобы я попала в полк, не могло быть и речи» [14; 2].

Н. Лобковская: «21-я дивизия у Неволя. В один прекрасный день, утром наши танки и автомашины врываются в г. Неволь. Немцев, офицеров в городе мы захватили в подштанниках. Представьте, 
были такие моменты: приходишь, стучишься, не открывают, открываешь дверь, и, что нас поразило, заставали в домах немцев с нашими русскими девушками. Ну тут пощады не было, на месте убивали.

Там было много трофеев. Это был большой опорный пункт немцев, и большие склады были, шоколад, конфеты, печенье, все было. Эти склады снабжали госпитали и там были большие запасы кондитерских изделий и много спиртных напитков, что было во вред нашим солдатам: напились, грабили и т.п. $[18 ; 6]$.

\section{Конкуренция среди своих}

В беседах девушки не скрывали фактов зависти, наличия конкуренции среди однополчанок. Но оценка этих моментов достаточно позитивная, работавшая на повышение результативности девушекснайперов.

А. Скрипочкина: «В землянке уже были командир батальона, заместитель по политчасти, комисcap, парторг. Из роты сообщили, что снайперский счет открыт. Моя пара Маша Зубченко обиделась, почему не она открыла счет и ревела вовсю. Командир батальона ее успокаивал. После этого началось соревнование, кто больше побьет немцев. Была некая Галеня из школы, она перебила всех. У нее было 16 фрицев.

Кто мечтал, особенно снайперская пара из 2 девушек. Одна говорила: «Как я убью немца, не представляю себе». Другая утешала: «Ну, ничего, как-нибудь убьем. Посмотрим и убьем» $[15 ; 5]$

Н. Лобковская: «Нам показали, как работали фрицы, чистили траншеи. А мы видели только одни каски. Это так раздражает - так и хочется выстрелить, но мы могли их спугнуть. И вдруг пошел какойто фриц. Мы его сразу обе заметили, вместе выстрелили и вместе уничтожили. Завязали спор, кому записать этого фрица. Сначала решили по половине, а потом записали Вере, поскольку она охотилась уже второй день [16;3].

До этого я 4 дня ходила и даже не видела немца. Я думала, что вообще не увижу и была очень расстроена. Я предпоследняя убила немца, уже 10 человек открыли счет, а нас двое никак, нет и нет, и мы приходили чуть не со слезами. И вот помню в этот раз я прихожу с хорошим настроением. А у нас сразу узнавали, кто убил, а кто не убил, потому как злой или веселый приходит. Ну, тут поздравляют, целуемся» $[17 ; 2]$.

\section{Чрезвычайные происшествия}

В материалах стенограммы сохранился еще один нетипичный факт: несчастный случай, смерть девушки во время учения, в результате неправильного, неумелого владения оружием у молодых девчонок, когда первые дни с боевым оружием на фронте воспринимались, как черновик, когда все можно изменить, переписать. Жестокая действительность войны проявила себя еще до настоящего сражения, у девушек - острое восприятие первой смерти: «Были убиты горем». В дальнейшем, рассказывая о потерях однополчан, подруг во время боев, смерть будет восприниматься ими как неотьемлемый элемент войны. И таких резко эмоциональных оценок будет меньше. Возможно, что эта реакция связана с нелепостью данной смерти; смерть во время сражения, казалось, имела смысл.

А. Скрипочкина: «В это время у нас погибла одна девушка Драйзен. Комбат приказала стрелять из ТТ. Две девушки пошли стрелять: одна стреляла по мишени, другая сидела на земле. Когда начальник сказал: «Кончайте стрелять», та, которая стреляла, опустила оружие и, очевидно, нажала спусковой крючок, даже не почувствовала, что выстрелила. Драйзен, которая сидела на земле, сказала: «Ты, Нина, кажется, меня ранила!». И побледнела. Оказалось, что пуля засела в животе. Ее даже не довезли до санчасти, она умерла дорогой. Когда умирала, говорила: «Ах, как бы хотелось убить, хотя бы одного фрица!». Это была одна из девушек, которая вела дневник. Все ополчились на Нину Крамерову, которая застрелила девушку, никто с ней не разговаривал. Если бы ни майор Никифорова, которая рассеяла эту атмосферу, с ней что-нибудь случилось бы» [15; 4].

Н. Лобковская: «В этот день у нас был несчастный случай. Нина Крамарева случайно убивает одну нашу девушку, не помню ее фамилию. Мы все были убиты горем, потеряв боевую подругу, не бывшую даже в бою. Начальство в испуге, не знает, чем это может кончиться» [17; 1-2].

\section{Обмундирование, быт}

Женские воспоминания сохраняют мелкие детали фронтовой повседневности: одежды и обмундирования, быта, жилища и т.д. Исследователи подчеркивают, что данные особенности женских воспоминаний демонстрируют механизмы адаптации женской психики в экстремальных условиях, переключая внимание на детали, кажущиеся неважными [19]. В воспоминаниях девушек трудности и 
дискомфорт по поводу огромных не по размеру сапог, выстриженного хохолка на голове вместо привычной длинной косы, брюки и шинель взамен платьев и юбок стояли по эмоциональному восприятию почти на одном уровне с преодолением таких проблем, как борьба с холодом, вшами, грязью и болезнями. Девушки озвучивали и проблемы физиологического плана, что для советских женщин 40-х гг. уже героизм.

Х. Доспанова: «Выдали обмундирования, дали сапоги 40 размера, а я ношу 33. Как быть? Учила майор Рочкевич накручивать портянки» $[14 ; 1]$.

А. Скрипочкина: «Нас 19 человек попали в 69-й полк. Поместили нас в такой маленькой земляночке, что набились как сельди в бочке. Расположились на полу».

Вопрос: «Как переносят фронтовую обстановку девушки?»

«Очень трудно, когда менструация. Нет бинтов, негде мыться. Девушки сказали об этом заместителю по комсомолу дивизии, он предложил санинструктору отпускать, сколько бинтов и ваты. Марши трудны, но приходится переносить. У некоторых менструация проходила с болью. Но ведь не будешь докладывать командиру батальона, что по такой причине не могу на охоту. Приходиться идти на охоту.

Было плохо с баней. Поэтому нам устроили банный день, так как мы белье стали стирать, чтобы иметь возможность постирать, посушить» [15; 4, 6-7].

Н. Лобковская: «В школе нас, прежде всего, определили на карантин. Девушки все обмундированы, а мы еще в гражданском. Смешно как-то - все в брюках, шинелях. На другой день нас стали одевать. Я чувствовала себя в брюках и гимнастерке очень неловко. Притом волосы у меня были раньше длинные, а тут нас обстригли, один хохолок остался. Шапку в здании по приказу надо было снимать, и я дико себя чувствовала $[16 ; 2]$.

Нас отозвали после ликвидации невельской группировки. Мы все мокрые, грязные, вшивые, в баню месяцами не ходили, всегда мокрые, сменить белье негде. Мы иногда ночевали в немецких землянках, а они очень вшивые. Помню, в одной землянке ночевали, очень маленькая была земляночка, а нас было человек 20 и разведчиков человек 16, землянка же, но больше, чем на 10 человек, нары были на 10 человек. Ночь была, достали какую-то свечку. А сено какое-то потертое, но не на голых же чурбаках спать, и мы легли. И вот улеглись, кто занял место, а мы поперек легли в ногах, сидя спим, тепло все-таки, печка топится. А когда утром встали и стали отряхиваться, то только шевелилось все кругом. Столько вшей заползло, что никак вывести не могли... Там у них много порошка от вшей было, сколько не насыпали, не помогло [17; 6].

Помню, я как-то раз заболела, температура у меня поднялась. Когда идешь днем - оттепель, а ночью - мороз, а мы в валенках, и полны валенки воды. Шуба на тебе тоже мокрая. И вот мы пришли, ничего нет, ни землянки, ни домов, меня сразу в санроту, температура поднялась до $39^{\circ}$, оказался грипп. Утром получили из штаба армии радиотелеграмму, чтобы нас всех отозвали. Мы идем в штаб дивизии, нам объявляют благодарности, мы садимся на машины и едем. Все очень довольны, что нас куда-то вызывают на отдых. Приезжаем в штаб армии. Мы находились в клубе, печурку разожгли, давай сушить портянки.

У нас была очень светлая, с электричеством палатка, растянутая в сосновом лесу. Приходим, сделаны нары, электричество горит, а мы впервые за все время электричество увидели. Разместились, разожгли большие печки-буржуйки, стало тепло, мы разделись. На следующий день приходит генерал, начальник штаба и член военного союза. Тут мы стали просить белье и баню. Нам выдали совершенно новое белье, но ватные брюки и шубы нам не заменили. И вот белье чистое, и все вши выползли на белье. На следующий день пришел генерал, и мы опять напали, чтобы выдали нам и шубы. Ну, привезли новые телогрейки, брюки новые и снова белье, опять поехали в баню, а на следующий день медосмотр и полнейшая санобработка [18; 6-7].

Прихожу в землянку, сырость, землянка течет, неприветливо, холодно, грязно. Мы всегда добывали сало, свечку, или какой-нибудь жир, и были мы, как первобытные люди. Сапоги у нас были кирзовые, большие, и хотя тут была высота, но вода была выше колена и мы все время в воде стояли.

Землянки потом построили хорошие, разберут дом и построят. Начальство обивало землянки сукном и бархатом $[17 ; 5]$.

А вы представить не можете, какие мы были: все время в глине, грязь высохнет на тебе, оботрешься и идешь дальше. Нас заводят в бараки этого армейского госпиталя; нары, заправленные простыни, шторочки. Как мы радовались, что будем спать на простынях, на наволочке. Ведь мы спали на хвое и хорошо, если плащ-палаткой покрыта, а то прямо на хвое. Шинелей не было, ватная курточка намокнет, намерзнешься, мокрая вся, свернешься и спишь $[17 ; 3]$. 
На следующий день утром к нам комиссия за комиссией: как нас одели, как нас обули, как мы себя чувствуем. К обеду пришла комиссия, которая хотела выяснить, чем мы еще не удовлетворены, потому что должно было приехать начальство из армии. Уже все мастерские работали для нас: кармашки, пуговицы перешивали, и к вечеру все обмундирование было подогнано на нас. Помню, сапоги большие выдавали, и в первый раз нам сапоги по ножке подогнали. Кирзовые сапоги, но подогнанные по ноге, так я прямо от радости прыгала» [17; 3].

Женская психика, еще менее приспособленная к войне, чем мужская, находит маленькие радости для отвлечения от горя, боли и страдания: «В первый раз нам сапоги по ножке подогнали. Кирзовые сапоги, но подогнанные по ноге, так я прямо от радости прыгала».

Действительно, что «женская память охватывает тот материк чувств на войне, который обычно ускользает от мужского внимания». «Женщина сильнее ощущала, опять-таки в силу своих психологических и физиологических особенностей, перегрузки войны - физические и моральные, а труднее переносила «мужской» быт войны» $[20 ; 61,62]$.

И все-таки только женщина, рассказывая о крайне тяжелых условиях жизни на фронте, как бы легко переключается на сравнение: «...сырость, землянка течет, холодно, грязно ... были мы, как первобытные люди... Землянки потом построили хорошие, разберут дом и построят. Начальство обивало землянки сукном и бархатом».

\section{Любовь на фронте}

Проблема взаимоотношений мужчин и женщин, любви, ухаживаний никогда не была исключена в рассказах женщин о войне. И даже краткие упоминания об этих моментах свидетельствуют, что мужское внимание, любовь были важными составляющими во фронтовой жизни для девушек.

$\mathrm{X}$. Доспанова: «Отношение девушек к парням имело различные стадии. В начале войны мы парировали всякие ухаживания. Ребят это терзало, мучило, злило. На второй год пошли увлечения, а на третий и четвертый год уже замужество. На замужество благословляла Бершанская, у нее же просили разрешения» $[14 ; 3]$.

А. Скрипочкина: «Вечером приехал генерал майор Михайлов, замечательный человек, с ним начальник политотдела дивизии. Нас выстроили, он поздоровался: «Приехали работать. Очень приятно. Учтите. Замуж у нас выходить нельзя, а влюбляться можно. Влюбитесь так, чтобы писать друг другу» $[15 ; 4]$.

Н. Лобковская: «Тут мы привели себя в порядок, подогнали обмундирование и даже волосы завили. А до этого мы были такие рваные, нам стыдно было выйти. А там все девушки штабные в шерстяном, по фигуре сшитом. Ну потом привели себя в порядок и высыпали на танцевальную площадку. В нашем распоряжении был баян. Дали приказание сделать большой клуб в штабе армии, начали рыть подземный клуб. На танцевальной площадке первые места на сцене занимали девушки, штабные, связные работницы, но снайпера появились, и вся площадка - в наших руках. А там связисты, медики, работники штабные, они никогда не были на переднем крае, и к нам было всеобщее внимание» [17; 7].

Насилие

Данная тема практически вообще не рассматривалась в казахстанской историографии и в целом достаточно редко в зарубежной. Рассказывая о войне, трудностях и проблемах военной действительности, фронтовики избегали этой темы. Для воспоминаний и бесед казахстанских женщин-фронтовиков тем более не характерны признания существования фактов насилия над женщинами на войне. Они предпочитали не говорить об этом, хотя факты такого рода не являлись редкостью. Существование такого явления, как ППЖ - походно-полевых жен, являлось попыткой защитить себя от домогательств (или получить привилегированные условия на фронте).

При изучении стенограмм бесед с тремя девушками мы сталкиваемся с фактом существования насилия в воспоминаниях одной из трех интервьируемых (причем одна из интервьюируемых $\mathrm{X}$. Доспанова служила в женском авиаполку). Причем девушка без возмущения говорит о благополучном исходе для мужчины-начальника факта применения насилия: «Его хотели исключить из партии, но потом оказалось, что из партии не исключили, а перевели куда-то на высшую должность», что свидетельствует о том, что данный факт не был беспрецедентным или чрезвычайным обстоятельством на фронте.

А. Скрипочкина: «Однажды начальник контрразведки вызывает одну девушку Зубченко в 11 часов вечера и спрашивает, как охотится, нет ли фрицев. Она отвечает, что есть наблюдатель, который наблюдает, действительно ли убит фриц или нет. Затем он ей говорит: «Я вас вызвал потому, что в 
полку была Зубченко, которая дезертировала из части. Может быть, это вы. Сходится год рождения, имя, фамилия. Но не сходится время приказа и место рождения». Ей нужно идти, а связных нет. Она говорит ему, чтобы он проводил. А он отвечает: «Не могу, сапоги жмут ноги, переночуйте тут». Он закрыл дверь и начал применять физическую силу. Ничего не добился, но девушка в 6 часов утра прибежала в слезах, вся исщипанная и искусанная. Его сняли с работы и куда-то отослали. Его хотели исключить из партии, но потом оказалось, что из партии не исключили, а перевели куда-то на высшую должность» $[15 ; 6]$.

\section{Заключение}

В центре внимания данной статьи находилась женская фронтовая повседневность с героизмом, ежедневным подвигом, самопожертвованием и при этом с ее проблемами и трудностями. Девушки «были готовы к подвигу, но не были готовы к армии, и то, с чем им пришлось столкнуться на войне, оказалось для них неожиданностью. Гражданскому человеку всегда трудно перестроиться на «военный лад». Армейская дисциплина, солдатская форма на много размеров больше, мужское оружие, тяжелые физические нагрузки - все это явилось нелегким испытанием» [17; 149]. Данное утверждение подтверждается материалами стенограмм: «Перед уходом в армию я представляла себе трудности на фронте, но я себе немного по-другому фронт представляла...» [18; 7]. Это, действительно, была та самая «будничная вещественность войны, о которой они, когда просились на фронт, не подозревали» [20; 101].

Анализируя тексты стенограмм, можно выявить закономерности восприятия женщинами войны, воссоздать «женскую картину» войны. Образ воюющей женщины «стереотипизирован современным сознанием» [19]. Долгое время господствовавший в историографии исключительно шаблонный, «героический» взгляд на фронтовую женщину сегодня меняется, проявляясь, как более глубокий, более многогранный и по-настоящему «очеловеченный» образ женщины-воина с ее разными эмоциональными проявлениями и реакциями на трудную военную действительность. Это позволяет, на наш взгляд, более полно воссоздать женскую военную повседневность.

Данная статья выполнена благодаря поддержке и в рамках реализации научно-исследовательского проекта Министерства образования и науки РК по грантовому финансированию АР5131992 «Великая Отечественная война и женщины Казахстана на фронтах и в тылу: женские истории и повседневность».

\section{Список литературы}

1 Комиссия по истории Великой Отечественной войны [Электронный ресурс]. — Режим доступа: http://www.iriran.ru

2 Советская историография / под ред. Ю. Н. Афанасьева. - М.: РГГУ, 1996. — 588 с.

3 Альтман М.М. Организация собирания и использования документов личного происхождения о Великой Отечественной войне (из опыта работы ЦГА СССР и Государственных архивов Российской Федерации: автореф. дис. ... канд. ист. наук / М.М. Альтман. — M., 1992. — 28 с. [Электронный ресурс]. — Режим доступа: https://www.dissercat.com

4 Минц И.И. Из Протокола редакционного совещания Комиссии. - 1945 г. История создания и деятельность Комиссии / И.И. Минц [Электронный ресурс]. — Режим доступа: http://www.iriran.ru

5 Вклад историков в сохранение исторической памяти о Великой Отечественной войне. На материалах Комиссии по истории Великой Отечественной войны АН СССР, 1941-1945 гг. / А.Г. Гуськов, К.С. Дроздов, С.В. Журавлев, В.Н. Круглов, Д.Д. Лотарева, В.В. Тихонов; отв.ред. С.В. Журавлев. - М.; СПб.: Центр гуманитарных инициатив, 2015. - 383 с.

6 Левшин Б.В. Деятельность Комиссии по истории Великой Отечественной войны, 1941-1945 гг. / Б.В. Левшин // История и историки: историографический ежегодник, 1974. - М., 1976. — С. 312-317.

7 Михайлова Е.П. О деятельности Комиссии по истории Великой Отечественной войны советского народа против фашистских захватчиков в период 1941-1945 гг. / Е.П. Михайлова // Вопросы историографии в высшей школе. - Смоленск, 1975. - С. 352-359.

8 Дроздов К.С. К истории создания Чрезвычайной государственной комиссии по установлению и расследованию злодеяний немецко-фашистских захватчиков / К.С. Дроздов // Археографический ежегодник / отв. ред. С.М. Каштанов. - М.: Русский фонд содействия образованию и науке, 2016. - С. 153-164.

9 «В период преследования противника от Москвы дело шло у нас особенно успешно»: стенограмма воспоминаний полковника Ф.Е. Двойнова о генерале-майоре Л.М. Доваторе / Публ. В.В. Тихонов // Исторический архив. — 2015. —№ 2. C. $48-61$.

10 Лотарева Д.Д. Комиссия по истории Великой Отечественной войны и ее архив: реконструкция деятельности и методов работы / Д.Д. Лотарева // Археографический ежегодник за 2011 г. — М., 2014. - C. 132-134.

11 Сталинградская битва: свидетельства участников и очевидцев. По материалам Комиссии по истории Великой Отечественной войны, 1941-1945 гг.; отв. ред. Й. Хелльбек. — М.: Новое литературное обозрение, 2015. — 672 с. 
12 Stalingrad. The City That Defeated the Third Reich / Jochen Hellbeck, ed. — New York: Public Affairs, 2015.

13 Hellbeck J. Die Stalingrad-Protokolle. Sowjetische Augenzeugen berichten aus der Schlacht. — Fischer Verlag GmbH, Frankfurt am Main, 2012.

14 Научный архив Института Российской истории Российской академии наук (НА ИРИ РАН). — Ф. 2. — Разд. І. — Оп. 216. - Д. 11. - Л. 1-3.

15 НА ИРИ РАН. - Ф. 2. — Разд. Х. - Оп. 7. - Д. 2а. - Л. 3-7.

16 НА ИРИ РАН. - Ф. 2. - Разд. Х. - Оп. 7. - Д. 7а. - Л. 1-12.

17 Сенявская Е.С. Психология войны в ХХ веке: исторический опыт России / Е.С. Сенявская. — М.: Рос. полит. энцикл. (РОССПЭН), 1999. - $383 \mathrm{c}$.

18 НА ИРИ РАН. - Ф. 2. - Разд. Х. - Оп. 7. - Д. 7б. - Л. 1-14.

19 Реброва И.В. «Женская» повседневность в проблемном поле истории Великой Отечественной войны / Женщина в российском обществе. — 2008 / И.В. Реброва [Электронный ресурс]. — Режим доступа: https://cyberleninka.ru/article

20 Алексиевич С. У войны не женское лицо: повести / С. Алексиевич. - М.: Сов. писатель, 1988. - 368 с.

\title{
3.Г. Сактаганова
}

\section{Ұлы Отан соғысы майдандарындағы әйелдердің күнделікті өмірі (Ұлы Отан соғысы тарихы бойынша Комиссия материалдарының негізінде)}

\begin{abstract}
Мақала Ұлы Отан соғысы майдандарындағы қазақстандық әйелдердің күнделікті өмірін зерттеуге арналған. Зерттеу жұмысының мақсаты - әйелдердің соғыс майдандарындағы күнделікті өмірінің (қиындықтары, тұрмысы, ерлер шовинизмі, зорлық-зомбылық) проблемалық кезеңдеріне назар аудару. Мақалада Ұлы Отан соғысының тарихы бойынша Комиссияның жинақтаған сұхбат материалдарының (РҒА РТИ Ғылыми архиві, 2-Қор) негізінде Ұлы Отан соғысы майдандарындағы Қазақстан әйелдерінің күнделікті өмірінің тарихы қарастырылған. Қазақстандық қыздардың соғысқа қатысуының тарихы мен тағдырының кейбір фрагменттеріне және олармен Ұлы Отан соғысы кезеңінде жүргізілген сұхбаттар стенограммасына талдау жасалған.
\end{abstract}

Кілт сөздер: Ұлы Отан соғысы, Қазақстан тарихы, Минц Комиссиясы, кеңес әйелдері, майдандағы әйелдер, әйелдердің күнделікті өмірі.

\section{Z.G. Saktaganova \\ Women's dayly life of on the fronts of World War II: Based on materials from the Commission on the History of the Great Patriotic War}

\begin{abstract}
The article is devoted to the study of everyday life of Kazakhstani women on the fronts of World War II. The purpose of this study is to actualize attention to the problematic issues of female front-line daily routines (difficulties, life, male chauvinism, violence). This article, based on interviews collected by the Commission on the History of the Great Patriotic War (Scientific Archive of the IRI RAS, Fund 2), tells the stories of everyday life of women in Kazakhstan on the fronts of the Great Patriotic War. Some plots of fate and stories of participation of Kazakhstani girls in the war were tracked; fragments of transcripts of conversations with them during the Great Patriotic War are given.
\end{abstract}

Keywords: World War II, the history of Kazakhstan, the Mintz Commission, Soviet women, women at the front, women's everyday life.

\section{References}

1 Komissiia po istorii Velikoi Otechestvennoi voiny [Commission on the history of the Great Patriotic]. www.iriran.ru Retrieved from http://www.iriran.ru [in Russian].

2 Afanasev, Yu.N. (Ed.). (1996). Sovetskaia istoriohrafiia [Soviet historiography]. Moscow: RGGU [in Russian].

3 Altman, M.M. (1992). Orhanizatsiia sobiraniia i ispolzovaniia dokumentov lichnoho proiskhozhdeniia o Velikoi Otechestvennoi voine (iz opyta raboty TsGA SSSR i hosudarstvennykh arkhivov Rossiiskoi Federatsii [Organization of the collection and use of documents of personal origin about the Great Patriotic War (from the experience of the Central Administration of the USSR and the state archives of the Russian Federation]. Candidate's thesis. Retrieved from https://www.dissercat.com [in Russian].

4 Mints, I.I. Iz Protokola redaktsionnoho soveshchaniia Komissii, 1945 h. Istoriia sozdaniia i deiatelnost Komissii [From the minutes of the editorial meeting of the Commission, 1945. History of the establishment and activities of the Commission]. www.iriran.ru Retrieved from http://www.iriran.ru 
5 Guskov, A.G., Drozdov, K.S., Zhuravlev, S.V., Kruglov, V.N., Lotareva, D.D., \& Tihonov, V.V. (Ed. S.V. Zhuravlev). (2015). Vklad istorikov v sohranenie istoricheskoi pamiati o Velikoi Otechestvennoi voine. Na materialakh Komissii po istorii Velikoi Otechestvennoi voiny. AN SSSR, 1941-1945 hh. [The contribution of historians to the preservation of the historical memory of the Great Patriotic War. Based on materials of the Commission on the History of the Great Patriotic War of the USSR Academy of Sciences]. Moscow; Saint Petersburg: Tsentr humanitarnykh initsiativ [in Russian].

6 Levshin, B.V. (1976). Deiatelnost Komissii po istorii Velikoi Otechestvennoi voiny, 1941-1945 hh. [Activities of the Commission on the History of the Great Patriotic War, 1941-1945]. Istoriia i istoriki: Istoriohraficheskii ezhehodnik - History and Historians: A Historiographic Yearbook, 312-317 [in Russian].

7 Mihaylova, E.P. (1975). O deiatelnosti Komissii po istorii Velikoi Otechestvennoi voiny sovetskoho naroda protiv fashistskikh zakhvatchikov v period 1941-1945 hh. [About the activities of the Commission on the history of the Great Patriotic War of the Soviet people against fascist invaders in the period 1941-1945]. Voprosy istoriohrafii v vysshei shkole - Questions of historiography in higher education. Smolensk [in Russian].

8 Drozdov, K.S. (2016). K istorii sozdaniia Chrezvychainoi hosudarstvennoi komissii po ustanovleniiu i rassledovaniiu zlodeianii nemetsko-fashistskikh zakhvatchikov [On the history of the creation of an extraordinary state commission for the establishment and investigation of the crimes of the Nazi invaders]. Arheohraficheskii ezhehodnik - Archaeological annual (Ed. S.M. Kashtanov). Moscow: Russkii fond sodeistviia obrazovaniiu i nauke [in Russian].

9 Tihonov, V.V. (2015). «V period presledovaniia protivnika ot Moskvy delo shlo u nas osobenno uspeshno»: stenohramma vospominanii polkovnika F.E. Dvoinova o henerale-maiore L.M. Dovatore [«During the period of the persecution of the enemy from Moscow, things were especially successful with us»: Transcript of the memoirs of Colonel F.E. Dvoinova about Major General L.M. Donator]. Istoricheskii arkhiv - Historical archive, 2, 48-61 [in Russian].

10 Lotareva, D.D. (2014). Komissiia po istorii Velikoi Otechestvennoi voiny i ee arkhiv: rekonstruktsiia deiatelnosti i metodov raboty [The Commission on the History of the Great Patriotic War and its archive: reconstruction of activities and working methods]. Arheohraficheskii ezhehodnik za 2011 h. - Archaeographic Yearbook 2011. Moscow [in Russian].

11 Hellbek, Y. (Ed.). (2015). Stalinhradskaia bitva: svidetelstva uchastnikov i ochevidtsev. Po materialam Komissii po istorii Velikoi Otechestvennoi voiny, 1941-1945 hh. [Battle of Stalingrad: testimonies of participants and eyewitnesses. Based on materials from the Commission on the History of the Great Patriotic War, 1941-1945]. Moscow: Novoe literaturnoe obozrenie [in Russian].

12 Hellbeck, J. (Ed.) (2015). Stalingrad. The City That Defeated the Third Reich, New York: Public Affairs.

13 Hellbeck, J. (2012). Die Stalingrad-Protokolle. Sowjetische Augenzeugen berichten aus der Schlacht. Frankfurt am Main: Fischer Verlag GmbH.

14 Nauchnyi arkhiv Instituta Rossiiskoi istorii Rossiiskoi Akademii nauk [Scientific archive of the Institute of Russian History of the Russian Academy of Sciences]. F. 2, S. I, Inv. 216, C. 11, Sh. 1-3 [in Russian].

15 Nauchnyi arkhiv Instituta Rossiiskoi istorii Rossiiskoi Akademii nauk [Scientific archive of the Institute of Russian History of the Russian Academy of Sciences]. F. 2, S. X, Inv. 7, C. 2a, Sh. 3-7 [in Russian].

16 Nauchnyi arkhiv Instituta Rossiiskoi istorii Rossiiskoi Akademii nauk [Scientific archive of the Institute of Russian History of the Russian Academy of Sciences]. F. 2, S. X., Inv. 7, C. 7a, Sh. 1-12 [in Russian].

17 Senyavskaya, E.S. (1999). Psikholohiia voiny v XX veke: istoricheskii opyt Rossii [Psychology of the war in the twentieth century: the historical experience of Russia]. Moscow: Rossiiskaia politicheskaia entsiklopediia (ROSSPEN) [in Russian].

18 Nauchnyi arkhiv Instituta Rossiiskoi istorii Rossiiskoi Akademii nauk [Scientific archive of the Institute of Russian History of the Russian Academy of Sciences]. F. 2, S. X, Inv. 7, C. 7б, Sh. 1-14 [in Russian].

19 Rebrova, I.V. «Zhenskaia» povsednevnost v problemnom pole istorii Velikoi Otechestvennoi voiny / Zhenshchina v rossiiskom obshchestve, 2008. cyberleninka.ru Retrieved from https://cyberleninka.ru/article [in Russian]. sian].

20 Aleksievich, S. (1988). U voiny ne zhenskoe litso [The war does not have a female face]. Moscow: Sovetskii pisatel [in Rus- 